\title{
Eleições 2016 em Maringá: a "mudança" contínua continua
}

- Enviado em 15/09/2016

- Aprovado em 18/09/2016
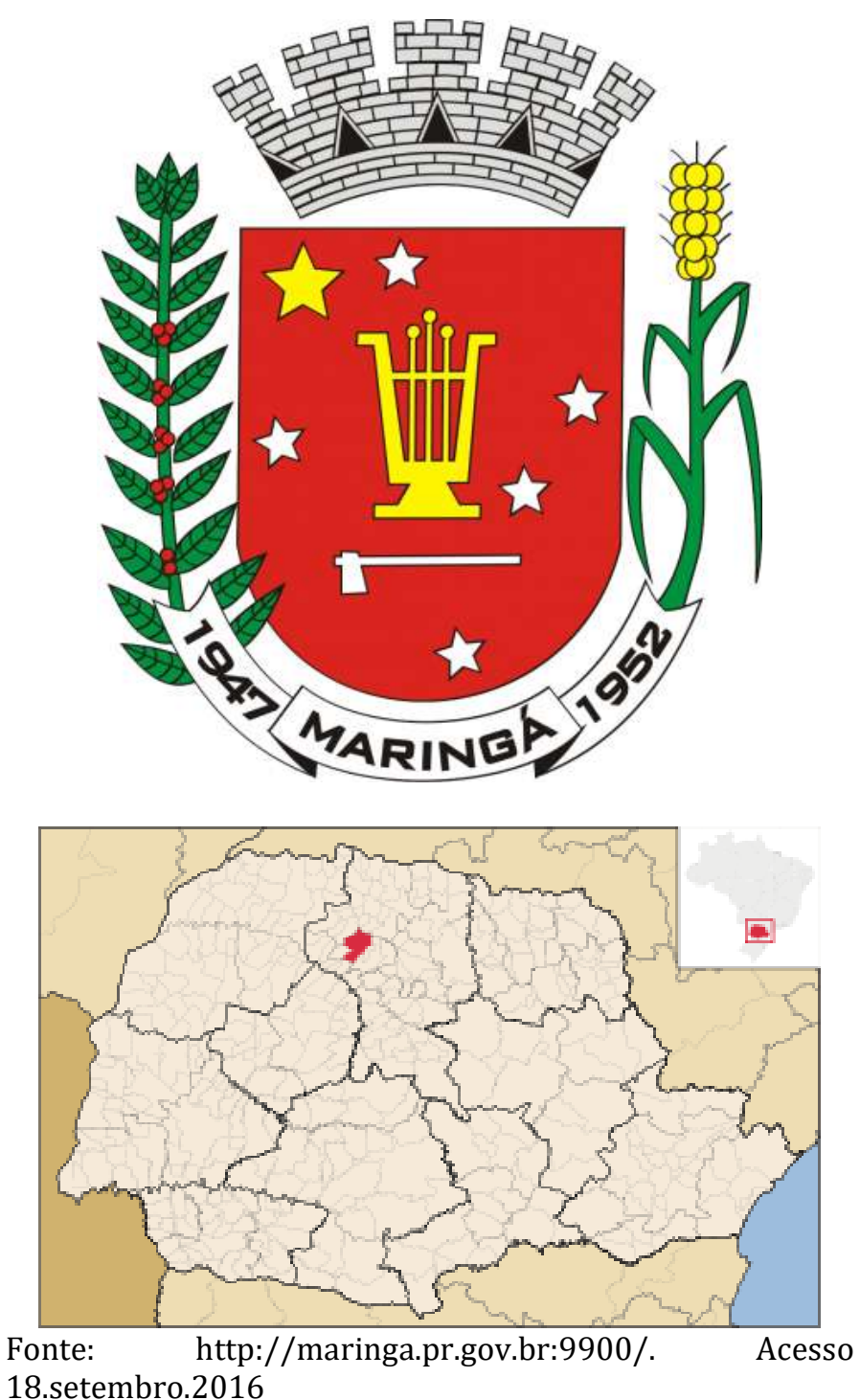

${ }^{1}$ Doutor em Sociologia pela Universidade Federal do Paraná (UFPR), Mestre e Graduado em Ciências Sociais pela Universidade Estadual de Maringá (UEM). Endereço eletrônico: tiagovalenciano.com 


\section{Eleições 2016 em Maringá: a “mudança” contínua continua}

Tiago Valenciano

As eleições 2016 em Maringá seguem com praticamente as mesmas lideranças disputando a Prefeitura Municipal. Com pequenas variações relacionadas aos grupos políticos existentes, a disputa perpassa por 8 candidatos, número idêntico ao do pleito anterior de 2012. Já a Câmara Municipal conta com 263 nomes para o certamente, número este reduzido em relação à 2012 - em virtude das alterações provenientes da legislação eleitoral.

O grupo político com maior intensidade na disputa é capitaneado pelo ex-Prefeito Silvio Magalhães Barros II (PP), que chefiou o executivo entre 2005 e 2012, por dois mandatos seguidos. Sucedido pelo atual prefeito Carlos Roberto Pupin (PP), Silvio Barros é filho de Silvio Magalhães Barros, Prefeito de Maringá entre 1973 e 1976, além de ter exercido o mandato de Deputado Federal. Silvio é irmão do atual Ministro da Saúde, Ricardo José Magalhães Barros (PP), que exerce o quinto mandato como Deputado Federal. Ricardo também foi Prefeito entre 1989 e 1992. Sua esposa, Maria Aparecida Borghetti (PP) é ViceGovernadora do Paraná e sua filha Maria Victoria Borghetti Barros (PP) exerce o primeiro mandato como Deputada Estadual, além de disputar a Prefeitura de Curitiba. A Vice-Prefeita escolhida por Silvio é Akemi Nishimori (PR), que já havia disputado as eleições de 1996 com o próprio Silvio e havia sido vice de João Ivo Caleffi em 2008. Akemi é esposa do Deputado Federal Luiz Hiloshi Nishimori (PR).

O segundo grupo que disputa a Prefeitura Municipal é liderado pelo Vereador Humberto José Henrique (PT), que exerce o segundo mandato na Câmara Municipal, além de ter disputado uma cadeira para a Assembleia Legislativa do Paraná em 2014. Humberto tem como Vice-Prefeita a professora de Sociologia Ana Lúcia Rodrigues (PC do B), que estreia eleitoralmente. O Deputado Federal Enio Verri (PT) optou em manter a candidatura de seu irmão Mário Verri (PT) para a Câmara Municipal.

Já o Vereador Ulisses de Jesus Maia Kotsifas (PDT) disputa a Prefeitura Municipal pela segunda vez. Exercendo o mandato na Câmara Municipal de Maringá também pela segunda oportunidade, Ulisses Maia é irmão do ex-Deputado Estadual e Vereador em Maringá Ricardo Maia. Seu Vice-Prefeito é Edson Scabora (PV), empresário no ramo da educação. 
Disputa ainda a Prefeitura de Maringá o advogado Wilson Darienzo Quinteiro (PSB) pela quarta oportunidade. Quinteiro foi diretor do BRDE (Banco Regional de Desenvolvimento da Região Sul) além de ter exercido por duas vezes, na condição de suplente, o mandato de Deputado Estadual. Seu pai Wilson Quinteiro foi Vereador em Barbosa Ferraz e Vice-Prefeito em Fênix, municípios próximos à Maringá. O Vice-Prefeito na chapa de Quinteiro é o empresário Francisco Favoto (DEM).

O Vereador Flávio Marcelo Gonçalves Vicente (REDE) disputa a Prefeitura Municipal pela primeira vez. Empresário e professor universitário, Flávio tem como Vice-Prefeita a advogada Cristiane Casado (REDE). Outras três candidaturas de menor expressão também compõem o pleito: o empresário Herculano Ferreira (PT do B) tem como Vice-Prefeito Clóvis Pontes (PT do B); a professora Priscila Guedes (PSTU) forma a chapa com o estudante Philip Natal (PSTU); e o Investigador Nilson Américo (PSOL) disputa com Bombeiro Nonato (PSOL).

Para a Câmara Municipal temos algumas disputas interessantes como a dos irmãos Angelo Salgueiro (PSD) e Hermes Salgueiro (PSC); Flávio Mantovani (PPS) concorre a uma cadeira na Câmara Municipal que outrora foi ocupada por quatro oportunidades por seu pai Paulo Mantovani; e Marquinhos Alves (PHS) que foi Vice-Prefeito entre 1997 e 2000 disputa novamente uma vaga no Poder Legislativo, este que é filho do ex-Deputado Estadual José Alves. 